\title{
Changes in the contents of kaempherol, quercetin and L-ascorbic acid in sea buckthorn berries during maturation
}

\author{
Niklas Jeppsson, Xiangqun Gao \\ Swedish University of Agricultural Sciences, Balsgård - Department of Horticultural Plant Breeding, \\ Fjälkestadsvägen 123-1, S-29194 Kristianstad, Sweden, e-mail: niklas.jeppsson@hvf.slu.se
}

\begin{abstract}
The contents of kaempherol, quercetin and L-ascorbic acid in sea buckthorn berries were measured at different maturation stages using High Performance Liquid Chromatography (HPLC) methods. The content of ascorbic acid decreased over time with significant differences between sampling dates for the five cultivars studied. The mean decrease was $25 \%$ in 19 days, from 1.48 to $1.10 \mathrm{~g} \mathrm{~kg}^{-1}$. Quercetin decreased whereas kaempherol increased during maturation. Among three studied cultivars, the decrease in quercetin was significant (from 0.028 to $0.014 \mathrm{~g} \mathrm{~kg}^{-1}$ ) in 'Otradnaja', where as the increase (from 0.012 to $0.016 \mathrm{~g} \mathrm{~kg}^{-1}$ ) in kaempherol was significant in the others two, 'Prozratnaja' and 'Gibrid Pertjik'.
\end{abstract}

Key words: antioxidants, ascorbic acid, flavonols, Hippophae rhamnoides, small fruits

\section{Introduction}

Sea buckthorn (Hippophae rhamnoides L., Elaeagnaceae) is a temperate bush growing in Europe and Asia (Rousi 1971). It was used as a medicinal plant in Tibet already in AD $900(\mathrm{Lu}$ 1992). Domestication started in Siberia in the 1930s by selection in native germplasm. Since then numerous cultivars of sea buckthorn for berry production have been released from several breeding programs in Russia (Kalinina and Panteleyeva 1987). A breeding program in Germany has also, since the onset in the 1970s, released cultivars for berry production (Albrecht 1990). In 1986 a project was started in Sweden, with the aim to introduce large scale cultivation for berry production (Trajkovski and Jeppsson 1999). The berries can be processed into e.g. juice and jam as well as used for flavouring of dairy products. In addition to the unique taste of sea buckthorn berries, their high contents of health promoting compounds could be used to boost marketing.

The strong association between fruit and vegetable intake and cancer prevention has been explained by the content of antioxidant nutrients (Block et al. 1992, Ames et al. 1995). Besides the commonly mentioned antioxidants (ascorbic acid, tocopherols and carotenoids) also flavonoids may act as cancer preventing nutrients (Ames et al. 1995) and contribute significantly 
Jeppsson, N. \& Gao, X. Changes in fruit quality in sea buckthorn berries

to the antioxidative activity of the diet (RiceEvans et al. 1997). The antioxidant activity varies among different flavonoids with e.g. 3.6 times higher activity for quercetin than for kaempherol (Rice-Evans et al. 1997). In a survey of 28 vegetables and 9 fruits for their contents of 5 flavonoids (the flavonols: quercetin, kaempherol and myricetin, and the flavones: luteolin and apigenin), selected as being potentially anticarcinogenic, kaempherol and quercetin were found to be the two major flavonoids. Quercetin was the most commonly occuring in the fruit samples, whereas kaempherol was present only in strawberries (Hertog et al. 1992).

The content of ascorbic acid varied between 0.28 and $2.01 \mathrm{~g} \mathrm{~kg}^{-1}$ in natural populations of sea buckthorn (ssp. rhamnoides) in Finland (Yao and Tigerstedt 1992). Among 17 Russian cultivars (ssp. mongolica), the content of ascorbic acid varied between 0.50 and $3.30 \mathrm{~g} \mathrm{~kg}^{-1}$ (Kalinina and Panteleyevna 1987). Four German cultivars varied between 1.50 and $3.40 \mathrm{~g} \mathrm{~kg}^{-1}$ (Albrecht 1990). In addition, sea buckthorn fruits contain the flavonols isorhamnetin, kaempherol and quercetin (Hörhammer et al. 1966).

The content of biochemical compounds should be considered not only in plant breeding but also in the evaluation of cultivation techniques and in choice of harvest date. Previously, L-ascorbic acid has been found to decrease (Rousi and Aulin 1977) whereas ice nucleation temperatures increased (Lundheim and Wahlberg 1998) in sea buckthorn berries during ripening. The present investigation was undertaken to study the influence of harvest date on the contents of L-ascorbic acid, kaempherol and quercetin in berries from various sea buckthorn cultivars.

\section{Material and methods}

The Russian cultivars 'Otradnaja', 'Prozratnaja', 'Gibrid Pertjik', 'Soljnjetnaja ' and 'Aromatnaja' grown at a production field at Balsgård -
Department of Horticultural Plant Breeding $\left(56^{\circ} 7^{\prime} \mathrm{N}, 14^{\circ} 10^{\prime} \mathrm{E}\right)$ were used for this study. Fruit samples were collected from the same individual of each cultivar on 6, 11, 14, 18, 21 and 25 August, 1997 , and stored at $-20^{\circ} \mathrm{C}$ until analyses. This sampling period should cover a reasonable time range for commercial harvesting; the berries were unpalatable before 6 August, and would be difficult to harvest due to loss in firmness after 25 August.

\section{L-Ascorbic acid}

Three replicate samples of $5 \mathrm{~g}$ of frozen berries from each date and each of the cultivars 'Otradnaja', 'Prozratnaja', 'Gibrid Pertjik', 'Soljnjetnaja' and 'Aromatnaja' were thawed at room temperature and homogenised in $50 \mathrm{ml}$ distilled water with a hand mixer for 10 seconds. After filtering, the filtrate $(10 \mu \mathrm{l})$ was injected for High Performance Liquid Chromatography (HPLC) analysis (Reversed Phase C8 column). Mobile phase was $50 \mathrm{mM} \mathrm{NH}_{4} \mathrm{H}_{2} \mathrm{PO}_{4}(\mathrm{pH} 2.6)$, and ascorbic acid was detected at $255 \mathrm{~nm}$. L-ascorbic acid purchased from Merck was used to produce a calibration curve.

\section{Flavonols}

Three replicate samples of $5 \mathrm{~g}$ of frozen berries from each date and each of the cultivars 'Otradnaja', 'Prozratnaja' and 'Gibrid Pertjik' were thawed at room temperature and homogenised in $15 \mathrm{ml}$ distilled water with a hand mixer for 15 seconds. The mixtures were supplied with $25 \mathrm{ml}$ methanol and $10 \mathrm{ml}$ of $6 \mathrm{M} \mathrm{HCl}$. After hydrolysis at $35^{\circ} \mathrm{C}$ for 16 hours, $1 \mathrm{ml}$ of the filtrate was freeze dried and the residue was dissolved in $2 \mathrm{ml}$ methanol. After being filtered through a millipore filter $(45 \mu \mathrm{m})$, the sample was injected for HPLC analysis (RP C8 column). The HPLC analysis was performed using the following system: solvent A: $0.2 \mathrm{mM}$ o-phosphoric acid (pH 1.5), solvent B: $20 \%$ of $50 \mathrm{mM} \mathrm{NH}_{4} \mathrm{H}_{2} \mathrm{PO}_{4}$ (pH 2.6) and $80 \%$ acetonitril, using a gradient: 
Vol. 9 (2000): 17-22.

Table 1. The content of L-ascorbic acid $\left(\mathrm{g} \mathrm{kg}^{-1}\right)$ during maturation. Entries with the same letter within each column are not significant at $5 \%$ level of significance.

\begin{tabular}{|c|c|c|c|c|c|c|c|c|c|c|c|c|}
\hline \multirow{2}{*}{$\frac{\text { Date }}{6 \mathrm{Aug}}$} & \multicolumn{2}{|c|}{ 'Otradnaja' } & \multicolumn{2}{|c|}{ 'Prozratnaja' } & \multicolumn{2}{|c|}{ 'Gibrid Pertjik' } & \multicolumn{2}{|c|}{ 'Aromatnaja' } & \multicolumn{2}{|c|}{ 'Soljnjetnaja' } & \multicolumn{2}{|c|}{ Mean } \\
\hline & 1.70 & a & 1.10 & $\mathrm{a}$ & 1.76 & $\mathrm{a}$ & 1.73 & $\mathrm{a}$ & 1.11 & $\mathrm{a}$ & 1.48 & $\mathrm{a}$ \\
\hline 11 Aug & 1.54 & $\mathrm{~b}$ & 1.05 & $\mathrm{a}$ & 1.80 & $\mathrm{a}$ & 1.68 & $\mathrm{a}$ & 1.05 & $\mathrm{~b}$ & 1.42 & b \\
\hline 14 Aug & 1.54 & $\mathrm{~b}$ & 0.99 & $\mathrm{~b}$ & 1.68 & $\mathrm{ab}$ & 1.69 & $\mathrm{a}$ & 0.94 & $\mathrm{~cd}$ & 1.37 & $\mathrm{c}$ \\
\hline $18 \mathrm{Aug}$ & 1.50 & $\mathrm{~b}$ & 0.96 & $\mathrm{~b}$ & 1.57 & $\mathrm{~b}$ & 1.49 & $\mathrm{~b}$ & 0.93 & $\mathrm{~d}$ & 1.29 & d \\
\hline $21 \mathrm{Aug}$ & 1.32 & $\mathrm{c}$ & 0.89 & $\mathrm{c}$ & 1.39 & $\mathrm{c}$ & 1.39 & $\mathrm{bc}$ & 0.82 & ef & 1.16 & $\mathrm{e}$ \\
\hline $25 \mathrm{Aug}$ & 1.25 & $\mathrm{c}$ & 0.85 & $\mathrm{c}$ & 1.28 & $\mathrm{c}$ & 1.33 & $\mathrm{c}$ & 0.80 & $\mathrm{f}$ & 1.10 & $\mathrm{f}$ \\
\hline$C V^{I}$ & 1.13 & & 0.97 & & 1.31 & & 1.07 & & 1.22 & & 2.49 & \\
\hline
\end{tabular}

$1 \quad \mathrm{CV}=$ Coefficient of variation

25-80\% solvent B (10-40 min). Flavonols were detected at $360 \mathrm{~nm}$. Among the resulting peaks, two (peak a and peak b) were identified as quercetin and kaempherol through comparison of (1) retention times with standards and (2) recorded UV spectra of samples on-line with those of standards. Retention times differed $<0.7 \%$ between peak a and quercetin and $<1.2 \%$ between peak $b$ and kaempherol. Similarity indices, for the spectra recorded in the range of ultraviolet light, between peak a and quercetin was 0.994 and between peak $b$ and kaempherol 0.997. For the calibration curve $(n=6)$ for kaempherol, $r^{2}$ was 0.966 and for quercetin $(n=6) r^{2}$ was 0.969 .

For both analysis of L-ascorbic acid and flavonols, the chemicals used were of the highest quality available and purchased from Sigma (USA) and Merck (Germany). Statistical analyses of the results were carried out with ANOVA (SuperANOVA, v. 1.11). For calibration curves, regression in SYSTAT v. 5.2.1 was used.

\section{Results and discussion}

\section{L-ascorbic acid}

The content of L-ascorbic acid in our study was somewhat lower (at the end of August 0.80-1.33 $\mathrm{g} \mathrm{kg}^{-1}$, Table 1) than previously reported for sea buckthorn of comparable origin (i.e. cultivars derived from ssp. mongolica and/or ssp. rhamnoides. Six clones from native stands in Finland (ssp. rhamnoides) varied from 1.70 to $2.90 \mathrm{~g} \mathrm{~kg}^{-1}$ at harvest on 1st September (Rousi and Aulin 1977). Among 17 Russian cultivars (ssp. mongolica), the content of ascorbic acid varied from 0.50 to $3.30 \mathrm{~g} \mathrm{~kg}^{-1}$ (Kalinina and Panteleyevna 1987). Four German cultivars varied from 1.50 to $3.40 \mathrm{~g} \mathrm{~kg}^{-1}$ (Albrecht 1990). The reported range may be due to variation between genotypes, years, cultivation sites and/or analytical methods. For comparison, other subspecies of $H$. rhamnoides may contain even higher amounts, with $6.20-8.30 \mathrm{~g} \mathrm{~kg}^{-1}$ being reported for H.r. ssp. sinensis (Ma et al. 1989) and an average of 8.30 $\mathrm{g} \mathrm{kg}^{-1}$ (maximum 13.30 $\mathrm{g} \mathrm{kg}^{-1)}$ for H. $r$. ssp. fluviatilis (Stocker 1948).

The analysed cultivars can be divided into two groups according to the content of L-ascorbic acid. One group, including 'Otradnaja', 'Gibrid Pertjik' and 'Aromatnaja', shows a comparatively high content of L-ascorbic acid, at the start of ripening, 1.70 to $1.76 \mathrm{~g} \mathrm{~kg}^{-1}$. Another group, including 'Prozratnaja' and 'Soljnjetnaja', contains much less L-ascorbic acid, 1.10 to $1.11 \mathrm{~g} \mathrm{~kg}^{-1}$. However, the content of ascorbic acid decreased significantly over ripening time for all cultivars (Table 1), and when the mean of all cultivars were compared, significant differences were found between all sampling dates. The 


\section{Jeppsson, N. \& Gao, X. Changes in fruit quality in sea buckthorn berries}

Table 2. The contents of quercetin and kaempherol $\left(\mathrm{g} \mathrm{kg}^{-1}\right)$ during maturation. Entries with the same letter within each column are not significant at $5 \%$ level of significance.

\begin{tabular}{|c|c|c|c|c|c|c|c|c|}
\hline \multirow[b]{2}{*}{ Quercetin } & \multirow{2}{*}{$\frac{\text { Date }}{6 \text { Aug }}$} & \multicolumn{2}{|c|}{ 'Otradnaja' } & \multicolumn{2}{|c|}{ 'Prozratnaja' } & \multicolumn{2}{|c|}{ 'Gibrid Pertjik' } & Mean \\
\hline & & 0.028 & $\mathrm{a}$ & 0.024 & $\mathrm{a}$ & 0.013 & $\mathrm{a}$ & $0.021 \quad \mathrm{a}$ \\
\hline & 11 Aug & 0.027 & $\mathrm{a}$ & 0.023 & $\mathrm{a}$ & 0.010 & $\mathrm{a}$ & 0.020 \\
\hline & 14 Aug & 0.024 & $\mathrm{a}$ & 0.026 & a & 0.015 & $\mathrm{a}$ & $0.021 \quad \mathrm{a}$ \\
\hline & $18 \mathrm{Aug}$ & 0.014 & $\mathrm{~b}$ & 0.015 & $\mathrm{a}$ & 0.012 & a & $0.014 \mathrm{c}$ \\
\hline & $21 \mathrm{Aug}$ & 0.022 & $\mathrm{a}$ & 0.023 & $\mathrm{a}$ & 0.012 & $\mathrm{a}$ & $0.019 \mathrm{ab}$ \\
\hline & $25 \mathrm{Aug}$ & 0.014 & $\mathrm{~b}$ & 0.019 & $\mathrm{a}$ & 0.013 & a & $0.015 \mathrm{bc}$ \\
\hline Coefficient of variation & & 30.8 & & 22.9 & & 25.7 & & 36.2 \\
\hline \multirow[t]{6}{*}{ Kaempherol } & $6 \mathrm{Aug}$ & 0.015 & $\mathrm{a}$ & 0.012 & $\mathrm{~b}$ & 0.012 & $\mathrm{c}$ & $0.013 \mathrm{c}$ \\
\hline & $11 \mathrm{Aug}$ & 0.015 & $\mathrm{a}$ & 0.013 & $\mathrm{~b}$ & 0.013 & $\mathrm{bc}$ & $0.013 \mathrm{bc}$ \\
\hline & 14 Aug & 0.016 & $\mathrm{a}$ & 0.014 & $\mathrm{~b}$ & 0.013 & $\mathrm{bc}$ & $0.014 \mathrm{~b}$ \\
\hline & $18 \mathrm{Aug}$ & 0.015 & $\mathrm{a}$ & 0.014 & $\mathrm{~b}$ & 0.014 & $\mathrm{~b}$ & $0.014 \quad b$ \\
\hline & $21 \mathrm{Aug}$ & 0.016 & $\mathrm{a}$ & 0.016 & $\mathrm{a}$ & 0.014 & $\mathrm{~b}$ & $0.016 \quad \mathrm{a}$ \\
\hline & $25 \mathrm{Aug}$ & 0.016 & $\mathrm{a}$ & 0.016 & $\mathrm{a}$ & 0.016 & $\mathrm{a}$ & 0.016 \\
\hline Coefficient of variation & & 37.2 & & 12.7 & & 11.1 & & 11.2 \\
\hline
\end{tabular}

mean decrease for the five cultivars was $25 \%$ in 19 days.

This is consistent with a previous investigation, in which six clones from native stands in southwestern Finland were studied. The content of L-ascorbic acid in the fruits decreased in all clones by $25-60 \%$ from 17 August to 21 September (i.e. 34 days) (Rousi and Aulin 1977). In addition, L-ascorbic acid content in fruits decreased during the ripening process also in two other members of the Elaeagnaceae family, Elaeagnus multiflora and E. umbellata (Sakamura and Suga 1987). For Citrus species ascorbic acid has been reported to decrease or remain constant during fruit ripening (Baldwin1993).

According to Rogiers et al. (1998), oxidative stress increased during berry ripening in Amelanchier alnifolia due to decreased activity of enzymes responsible for the scavenging of free radicals. Ascorbic acid, as an antioxidant, inhibits the activity of peroxidases (Prestamo and Manzano 1993) and is therefore capable of decreasing oxidative stress. Thus, the decrease in ascorbic acid content in sea buckthorn berries during ripening could be a prerequisite for the ripening process.

\section{Flavonols}

The contents of quercetin and kaempherol in sea buckthorn berries changed significantly during maturation, but in different directions. In 'Otradnaja', the content of quercetin decreased over the time range with a small peak at August 21 (Table 2). The amount at 6 August was twice as high as at 25 August. No significant differences were found in the other two cultivars 'Prozratnaja' and 'Gibrid pertjik'. The calculated mean values, based on the three cultivars, decreased significantly, interrupted by a peak at 21 August. The overall decrease from 6 to 25 August was $29 \%$. The peak at 21 August cannot be explained by artefacts in the experimental set up since the cultivars were analysed separately, with samples from all harvest dates analysed at the same occasion. Instead, the peak may have been caused by variation in the weather conditions.

In contrast to quercetin, the content of kaempherol increased significantly $(33 \%)$ in both 'Prozratnaja' and 'Gibrid pertjik' over the time range (Table 2). The mean values, based on the three cultivars, of kaempherol content increased with $23 \%$. Changes in flavonol contents have 
Vol. 9 (2000): 17-22.

been observed also in other fruit crops, e.g. in apple skin where concentration of quercetin-glucosides decreased significantly during ripening (Lister et al. 1994, 1996). By contrast, no correlation was found between flavonol content and degree of ripeness in raspberry (Rommel and Wrolstad 1993).

Obviously, the two flavonols, quercetin and kaempherol, changed in opposite directions during maturation. For quercetin, the content was stable between 6 and 14 August and then decreased, however interrupted by a peak at 21 August. For kaempherol, there was instead a steady increase from 6 to 25 August. Non-linear changes with peaks and valleys have been reported for phenolic compounds in grapes during ripening (Simon et al. 1993). They also found differences in the development of various phenolic compounds, with e.g. a marked increase of quercetin-3-rutinoside during ripening over a time range of one month, while the content of quercetin-3-galactoside and quercetin-3-glucoside remained fairly stable over the same interval. In two apple cultivars, the accumulation of flavonoids in the fruit skin was correlated with the activities of three enzymes involved in the flavonoid pathway (precursor biosynthesis, flavonoid synthesis and flavonoid modification respectively) (Lister et al.1996). Degradation and/ or inhibitors were believed to play a minor role.

\section{Harvest date recommendations}

Fruits of the German cultivars 'Hergo' and 'Leikora' have been scored for eleven biochem- ical and agronomical traits (Albrecht 1990). For determination of optimal harvest date, five traits were selected as having a major influence: fruit colour, total acidity, fruit weight, crop losses caused by mechanical harvesting and force needed to remove the berries from the branches. In 1987, the optimal harvest dates were estimated to fall in the 1st decade of September for 'Hergo' and in the 2nd decade for 'Leikora'. In the following year, they were one decade earlier for both cultivars. The recommended time range for mechanical harvest was 14 days. The content of ascorbic acid had already decreased to $75-80 \%$ of the maximum value at the recommended date for onset of harvest.

In our study, the content of L-ascorbic acid decreased markedly during maturation, which means that harvest should take place as early as possible to produce a crop rich in ascorbic acid. By comparison, the changes in flavonol contents during ripening were quite moderate. Since quercetin contributes to the antioxidant activity to a larger extent than kaempherol (Rice-Evans et al. 1997), more attention should be paid to the former. To achieve a high content of quercetin, harvest should again be performed as early as possible. However, additional factors like taste and fruit firmness must also be taken into account.

Acknowledgement. Thanks are due to Hilde Nybom for valuable comments on the manuscript. This study was funded by the Swedish Research Council for Forestry and Agriculture and The County Administration and The Regional Council in Kalmar county.

\section{References}

Albrecht, H.-J. 1990. Sortenentwicklung bei Sanddorn. Gartenbau 37: 207-208.

Ames, B.N., Gold, L.S. \& Willett, W.C. 1995. The causes and prevention of cancer. Proceedings of the National Academy of Sciences 92: 5258-5265.

Baldwin, E.A. 1993. Citrus fruit. In: Seymour, G.E. et al. (eds.). Biochemistry of fruit ripening. London: Chapman \& Hall. p. 107-149.

Block, G., Patterson, B. \& Subar, A. 1992. Fruits, vegetables, and cancer prevention: A review of the epidemiological evidence. Nutrition and Cancer 18: 129. 
Jeppsson, N. \& Gao, X. Changes in fruit quality in sea buckthorn berries

Hertog, M.G.L., Hollman, P.C.H. \& Katan, M.B. 1992. Content of potentially anticarcinogenic flavonoids of 28 vegetables and 9 fruits commonly consumed in the Netherlands. Journal of Agriculture and Food Chemistry 40: 2379-2383.

Hörhammer, L., Wagner, H. \& Khalil, E. 1966. Über die Flavonolglykoside der Früchte des Sanddorns (Hippophae rhamnoides). Lloydia 29: 225-229.

Kalinina, I.P. \& Panteleyeva, Y.I. 1987. Breeding of sea buckthorn in the Altai. In: Advances in Agricultural Science. Moscow, Russia. p. 76-87.

Lister, C.E., Lancaster, J.E., Sutton, K.H. \& Walker, J.R.L. 1994. Developmental changes in the concentration and composition of flavonoids in skin of a red and a green apple cultivar. Journal of the Science of Food and Agriculture 64: 155-161.

-, Lancaster, J.E. \& Walker, J.R.L. 1996. Developmental changes in enzymes of flavonoid biosynthesis in the skins of red and green apple cultivars. Journal of the Science of Food and Agriculture 71: 313-320.

Lu, R. 1992. Seabuckthorn: a multipurpose plant species for fragile mountains. Katmandu: ICIMOD publication unit. $62 \mathrm{p}$.

Lundheim, R. \& Wahlberg, K. 1998. Ice nucleation in fruit juice from different varieties of sea buckthorn Hippophae rhamnoides L. Euphytica 102: 117-124.

Ma, Z., Cui, Y. \& Feng, G. 1989. Studies on the fruit character and biochemical compositions of some forms within the Chinese sea buckthorn (Hippophae rhamnoides ssp. sinensis) in Shanxi, China. In: Proceedings of International Symposium on Sea Buckthorn (H. rhamnoides L.), Xian, China. p. 106-112.

Prestamo, G. \& Manzano, P. 1993. Peroxidases of selected fruits and vegetables and the possible use of ascorbic acid as an antioxidant. HortScience 28: 4850.

Rice-Evans, A.C., Miller, N. \& Paganga, G. 1997. Antioxidant properties of phenolic compounds. Trends in Plant Science 2: 152-159.

Rogiers, S.Y., Kumar, G.N.M. \& Knowles, N.R. 1998. Maturation and ripening of fruit of Amelanchier alnifolia Nutt. are accompanied by increasing oxidative stress. Annals of Botany 81: 203-211.

Rommel, A. \& Wrolstad, R.E. 1993. Composition of flavonols in red raspberry juice as influenced by cultivar, processing, and environmental factors. Journal of Agriculture and Food Chemistry 41: 1941-1950.

Rousi, A. 1971. The genus Hippophae L. A taxonomic study. Annales Botanici Fennici 8: 177-227.

- \& Aulin, H. 1977. Ascorbic acid content in relation to ripeness in fruits of six $\mathrm{H}$. r. clones from Pyhäranta, SW Finland. Annales Agriculturae Fenniae 16: 80-87.

Sakamura, F. \& Suga, T. 1987. Changes in chemical components of ripening oleaster fruits. Phytochemistry 26: 2481-2484.

Simon, B.F. de, Hernandez, T. \& Estrella, I. 1993. Phenolic composition of white grapes (var. Airen). Changes during ripening. Food chemistry 47: 47-52.

Stocker, O. 1948. Tiroler Sanddorn (Hippophae rhamnoidesL.) als Vitamin C-Höchtleitungspflanze. Züchter, 19: 9-13 (in German).

Trajkovski, V. \& Jeppsson, N. 1999. Domestication of sea buckthorn. Botanica Lithuanica, suppl. 2: 37-46.

Yao, Y. \& Tigerstedt, P.M.A. 1992. Variation of vitamin C concentration and character correlation between and within natural sea buckthorn (Hippophae rhamnoides L.) populations. Acta Agriculturae Scandinavica 42: 12-17.

\title{
SELOSTUS
}

\section{Tyrnin marjojen kamferoli-, kversetiini- ja L-askorbiinihappopitoisuuksien muutokset kypsymisen aikana}

\author{
Niklas Jeppsson ja Xiangqun Gao \\ Ruotsin maatalouskorkeakoulu
}

Tyrnimarjan kamferoli-, kversetiini- ja L-askorbiinihappopitoisuuksia mitattiin marjojen eri kypsymisvaiheissa suuren erotuskyvyn nestekromatografisella (HPLC) menetelmällä. Viiden tutkitun tyrnilajikkeen marjojen askorbiinihappopitoisuus pieneni mitä myöhemmin marjat kerättiin. Pitoisuus pieneni 19 päivän aikana keskimäärin $25 \%(1,48-1,10 \mathrm{~g} / \mathrm{kg})$.
Kversetiini-pitoisuus pieneni samalla kun kamferoli-pitoisuus suureni. Kolmen tutkitun lajikkeen kversetiini-pitoisuus pieneni Otradnaja-lajikkeella $(0,028-0,014 \mathrm{~g} / \mathrm{kg})$, kun taas kamferoli-pitoisuus suureni Prozratnaja- ja Gibrid Pertjik -lajikkeilla $(0,012-$ $0.016 \mathrm{~g} / \mathrm{kg}$ ). 